\title{
Tren-Tren Wacana Studi Al-Qur'an dalam Pandangan Orientalis di Barat
}

\author{
Oleh: Muhammad Anshori \\ Email: anshori92@gmail.com/087839234275 \\ Mahasiswa Doktor Studi Islam \\ Konsentrasi Studi Al-Qur'an dan Hadis \\ Pascasarjana UIN Sunan Kalijaga Yogyakarta
}

\begin{abstract}
This paper discusses about the history or trend of the Qur'anic studies in the West in general which is still developing until now. There are three focuses of discussion in this paper, namely the history of the translation of the Qurran, Jewish-Christian Influences on the Qur an, and a critical study of the Qurran. Before discussing this matter, this paper also discusses a little about Mushaf 'Usmānī or what is now called the Quran. The beginning of the study of the Quran in the West began with translation and later developed into a critical study of the Quran itself. The first translation of the Quran was carried out by Peter the Venerable and Abbot of Cluny in Latin. This translation was later refined by Robert of Ketton in 1143. After being translated, it was only published for the first time in 1543 AD. After the translation of this translation, it was later followed by other translations in various languages. The study of the Qur'an began to draw attention in the West when Theodor Nöldeke wrote a book on the history of the Qur'an (Geschichte des Qorāns/Tärìkh al-Qur'ān, The History of The Qurıan). Some Western scholars
\end{abstract}


said that the Quran has been influenced by the Judeo-Christian tradition and thus has some similarities. Some Western scholars also conduct critical studies of the Qur'an, some even want to make another version of the Quran. The views of Western scholars who are «eccentric» have been denied by Muslim scholars themselves. It can be said that this paper discusses the Orientalist views of the Qurran.

Keywords: Quranic Studies, Orientalists, Western World, Critical Studies.

Tulisan ini membahas tentang sejarah atau tren kajian Al-Quran di Barat secara umum yang sampai sekarang masih berkembang. Ada tiga fokus pembahasan dalam tulisan ini, yaitu: sejarah penerjemahan al-Qur'an, pengaruh Yahudi-Kristen terhadap al-Quran, dan kajian kritis terhadap al-Quran. Sebelum membahas hal tersebut, tulisan ini juga membahas sedikit tentang mushaf 'Us̉mānī atau yang sekarang disebut al-Quran. Awal mula studi Al-Qur'an di Barat dimulai dengan penerjemahan, kemudian berkembang menjadi studi kritis terhadap Al-Qur'an itu sendiri. Terjemahan Al-Qur'an pertama dilakukan oleh Peter the Venerable dan Abbot of Cluny ke dalam bahasa Latin. Terjemahan ini kemudian disempurnakan oleh Robert of Ketton pada tahun 1143. Setelah selesai diterjemahkan baru kemudian diterbitkan untuk pertama kalinya pada tahun $1543 \mathrm{M}$. Setelah munculnya terjemahan ini, baru kemudian disusul dengan terjemahan lainnya ke dalam berbagai bahasa. Kajian terhadap Al-Quran mulai menarik perhatian di Barat ketika Theodor Nöldeke menulis buku sejarah AlQuran (Geschichte des Qorāns/Tärìkh al-Qurān, The History of The Quran). Sebagian sarjana Barat mengatakan bahwa Al-Quran sudah dipengaruhi oleh tradisi Yahudi-Kristen sehingga memiliki beberapa kesamaan. Beberapa sarjana Barat juga melakukan studi kritis terhadap al-Qur'an, bahkan ada yang ingin membuat Al-Qur'an versi lain. Pandangan-pandangan sarjana Barat yang "nyeleneh" sudah dibantah oleh sarjana-sarjana Muslim sendiri. Bisa dikatakan bahwa tulisan ini membahas tentang pandangan orientalis terhadap al-Quran.

Kata Kunci: Studi Al-Qur’an, Orientalis, Dunia Barat, Kajian Kritis. 


\section{PENDAHULUAN}

Pada abad ke-19, setidaknya ada dua model citra dan persepsi Barat (Eropa) terhadap Islam. Pertama, menganggap Islam sebagai musuh dan rival Kristen. Kedua, menganggap Islam sebagai bentuk pencapaian akal dan perasaan manusia dalam usaha mereka untuk mengetahui dan merumuskan sifat Tuhan dan alam. Pada periode yang sama, semangat evangelisme (penginjilan), yang disertai dengan kolonialisme, mewarnai dunia dan masyarakat Islam. Ide dasar evangelisme adalah bahwa keselamatan (salvation) terletak hanya pada pengakuan dosa dan penerimaan Gospel Kristen. Ide dan semangat evangelisme ini menciptakan konfrontasi antara Kristen dan Muslim dalam skala lebih besar ketimbang masa-masa sebelumnya. Evangelisme membangkitkan kembali sikap permusuhan Eropa terhadap Islam. ${ }^{1}$

Salah satu bentuk permusuhan Barat terhadap Islam adalah dengan menghina atau menjelek-jelekkan al-Qur'an. Tentu tidak semua kalangan Barat melakukan hal demikian. Studi Al-Qur'an merupakan bagian dari Studi Islam (Islamic Studies) yang sangat digemari di dunia Barat. Hampir semua kampus atau Perguruan Tinggi di Barat menawarkan studi Islam dengan berbagai penyebutan seperti Middle East Studies, Near Eastern Studies, Religious Studies, Comparative Religion, dan lain-lain. Kajian terhadap Al-Qur'an mulai menarik perhatian di Barat ketika Theodor Nöldeke (1836-1930) menulis buku sejarah Al-Qur'an (Geschichte des Qorāns) yang kemudian diterbitkan pada tahun 1860 oleh Universitas Gottingen, Jerman.

Nöldeke membahas tentang sejarah muncul dan berkembangnya teks Al-Qur'an, pengumpulan, dan periwayatannya. Ia juga mempermasalahkan mengapa susunan Al-Qur'an tidak sesuai dengan masa turunnya. Kajian ini kemudian dilanjutkan oleh Friedrich

1 Azyumardi Azra, kata pengantar dalam buku Robert A. Morey, The Islamic Invasion (Islam Yang Dihujat), trj. Sadu Suud (Bekasi: C.V. Fokus Muslimedia, cet-II, 2005), hlm. 22. 
Schwally (w. 1919) pada tahun 1909 atas permintaan Nöldeke sendiri. Setelah Nöldeke menulis buku tersebut, Gustav Weil menulis juga tentang sejarah Al-Qur'an dalam buku Historisch-kritische Einleitung in der Koran (Mukaddimah al-Qur'an: Kritik Sejarah) yang terbit tahun 1884. Pada akhirnya, buku sejarah Al-Qur'an Geschichte des Qorānsdikumpulkan menjadi satu. Ada empat tokoh penulis buku tersebut yaitu Theodor Nöldeke, Friedrich Schwally, Gotthelf Begstrasser, dan Otto Pretzl. ${ }^{2}$

Kalangan orientalis mengkaji Al-Qur'an dari berbagai macam aspek, tentu yang dikaji bersumber dari teks-teks Al-Qur'an sendiri. Di antara nama-nama Orientalis yang melakukan studi kritis terhadap Al-Qur'an atau studi Islam secara umum adalah Abraham Geiger (1810-1874), Gustave Weil (1808-1889), William Muir (1819-1905), Theodor Nöldeke (1836-1930), Friedrich Schwally (w. 1919), Edward Sell (1839-1932), Hartwig Hirscfeld (1854-1934), David S. Margoliouth (1858-1940), W.St. Clair-Tisdall (1859-1928), Louis Cheikho (18591927), Paul Casanova (1861-1926), Julius Wellhausen (1844-1918), Charles Cutley Torrey (1863-1956), Leone Caetani (1869-1935), Joseph Horovits (1874-1931), Richard Bell (1876-1953), Alphonse Mingana (1881-1937), Israel Schapiro (1882-1957), Siegmund Fraenkel (1885-1925), Tor Andrae (1885-1947), Arthur Jeffery (1893-1959), Regis Blachere (1900-1973), W. Montgomery Watt, Kenneth Cragg, John Wansbrough (1928-2002), S.M. Zwemmer, Andrew Rippin, C. Luxenberg, Danial A. Madigan, Harald Motzki, dan lain-lain. ${ }^{3}$ Perlu

2 Buku ini telah diedit dan diterjemahkan ke dalam bahasa Inggris dengan judul The History of The Qurān oleh Wolfgang H. Behn (Leiden-Boston: Brill, 2013). Edisi terjemahan bahasa Arab oleh George Tamir, ikut juga dalam penerjemahan itu adalah 'Ablah Ma'lūfTamir, Khairuddīn 'Abdul Hādī dan Nuqula Abū Murād (Beirut: Mu’assasah Konrad Adenauer, 2004). Pada mulanya, buku ini diterbitkan dalam tiga volume, volume pertama ditulis oleh Theodor Nöldeke, volume kedua oleh Nöldeke dan Schwally dengan judulDie Sammlung des Qorans dan volume ketiga ditulis oleh Bergstrasser and Pretzl dengan judul Die Geschichte des Korantexts. Hanya volume kedua dan ketiga yang banyak membahas proses pengumpulan Al-Qur'an.

3 Lihat data saling melengkapi, Adnin Armas, Metodologi Bibel dalam Studi Al-Quran: 
diketahui bahwa kajian mereka tidak hanya terfokus pada studi alQur'an, tetapi studi Islam secara umum seperti hadis, sejarah, politik, filsafat, tasawuf, dan ilmu lainnya.

Pada tahun 1844, salah seorang orientalis bernama Rodinson ${ }^{4}$ melacak sejarah kajian orientalis yang dimulai sejak abad IV sampai pertengahan abad XX. Sumber yang digunakan adalah HistorischeKritische Einleitung in der Koran karya Gustav Weil (1808-1889). Weil merupakan sarjana Barat pertama yang membagi periodesasi Al-Quran menjadi empat, yaitu Makkīyah awal, tengah, akhir dan Madanīyah. Tesis tersebut kemudian diadopsi oleh Theodor Nöldeke (1836-1930) dan Friedrich Schwally (w. 1919) dalam Geshichte des Qorans. Karya Nöldeke dan Schwally mempengaruhi Regis Blachere dalam menulis terjemahan Al-Qur'an berjudul Le Coran: Troduction Selon un Essai de Reclassement des Sourates (1949-1950). ${ }^{5}$ Kajian Al-Qur'an sebelum Nöldeke dilakukan oleh seorang orientalis Jerman di Leizig, yaitu Gustave Flugel pada tahun 1834. Ia menerbitkan mushaf hasil kajian filologinya yang berjudul

Kajian Kritis (Jakarta: Gema Insani Press, cet-III, 1428 H/2007 M), hlm. 47-48. Daud Rasyid, "Pembaruan" Islam \& Orientalisme dalam Sorotan (Bandung: Syamil Publishing, cet-I, 2006), hlm. 126. Syamsuddin Arif, Orientalis \& Diabolisme Pemikiran (Jakarta: Gema Insani Press, cet-I, 1429 H/2008 M). 2-21. Fahmi Salim, Kritik Terhadap Studi AlQuran Kaum Liberal (Jakarta: Perspektif, cet-I, 1431 H/2010 M), hlm. 189-190. Sebagian nama orientalis tersebut penulis tambah berdasarkan hasil bacaan yang penulis lakukan dari berbagai sumber, termasuk dari karya Adian Husaini, Wajah Peradaban Barat: Dari Hegemoni Kristen ke Dominasi Sekular-Liberal (Jakarta: Gema Insani Press, cet-I, 1426 $\mathrm{H} / 2005 \mathrm{M})$.

4 Ihsan Ali Fauzi telah membahas pandangan Maxime Rodinson tentang citra dan studi Barat terhadap Islam dalam artikelnya, "Orientalisme di Mata Orientalis: Mixime Rodinson tentang Citra dan Studi Barat atas Islam”, Jurnal Ulumul Qur’an, Vol. 3, No. 2, 1992, hlm. 4-22. Fauzi membahas sejarah orientalisme melalui karya-karya Rodinson, "The Western Image and Western Studies on Islam", dalam Joseph Shacht and C.E. Bosworth (eds), The Legacy of Islam (Oxford: Oxford University Press, 1974), hlm. 9-62, demikian juga dengan karya Rodinson, Europe and the Mystique of Islam, trj. Roger Veinus (Seattle \& London: University of Washington Press, 1987), hlm. 3-82. Tulisan Fauzi banyak dikutip oleh Moeflich Hasbullah, Sejarah Intelektual Islam di Indonesia (Bandung: Pustaka Setia, ce-I, 2012), hlm. 322-328.

5 Hasani Ahmad Said, Diskursus Munasabah Alquran dalam Tafsir Al-Mishbah (Jakarta: Amzah, cet-I, 2015), hlm. 74-75. 
Corani Textus Arabicus. Beberapa kajian orientalis telah dikumpulkan dan diedit oleh Ibn Warraq dalam buku The Origins of The Koran: Classic Essays on Islam's Holy Book (New York: Prometheus Book, 1998).

Sebagian sarjana Barat di atas mengkaji sejarah Nabi Muhammad dan komunitas Muslim awal dengan merujuk kepada Al-Quran karena bagi mereka ia merupakan sumber yang paling terpercaya (the most reliable source for reconstruction of the life of Muhammad and the history of early Muslim community). ${ }^{6}$ Secara umum, kajian tentang orientalis telah ditulis oleh Edward W. Said ${ }^{7}$ dalam bukunya Orientalism. ${ }^{8}$ Buku ini memang cukup kontroversial di kalangan sarjana Barat dan sarjana Muslim. Said memang bukan satu-satunya pemikir yang menjadi pelopor kajian pasca-kolonial, karena sebelumnya sudah ada Aime Cesaire dengan bukunya From Discourse on Colonialism (1955), dan Frantz Fanon dalam buku The Fact of Blackless (1952). Akan tetapi buku Orientalism Said merupakan kajian pertama yang mengkritik ideologi kolonial secara diskursif. Perlu diketahui bahwa dalam tulisan ini, penulis hanya akan membahas tiga tema pokok seputar kajian AlQur'an di Barat.

6 Jane Dammen McAuliffe, kata pengantar dalam Encyclopedia of the Qurān, jilid-I (Leiden: Brill, 2001), hlm. viii.

7 Edward Said lahir pada tanggal 1 November 1935 di Yerusalem, tepatnya di daerah Talbiyah (sebuah kawasan terpencil di Palestina Barat). Ia harus mengungsi ke Mesir pasca kekalahan Palestina pada tahun 1947, dan menjadi imigran di Amerika Serikat pada tahun 1951. Sejak lahir, Said memang tidak pernah lepas dari paradoks identitas. Hidup di lingkungan Palestina yang mayoritas Muslim ia memiliki nama depan Edward (Inggris), nama tengah Wadie (nama ayahnya yang berbisnis di Kairo), dan nama akhir Said (Arab). Edward Said meninggal pada hari Kamis, 23 September 2003 di Rumah Sakit New York, tepat dalam usia 67 tahun. Penyakit Leukemia akut yang dideritanya sejak 1992 membuat Said harus berjuang sendirian, persis ketika ia memperjuangkan masalah yang sama kronisnya sejak lebih dari dua dekade perjalanan karirnya sebagai seorang intelektual. Meski demikian, empat bulan sebelum Said menghembuskan napas terakhir, ia masih sempat menulis prolog untuk buku Orientalism-nya pada bulan Mei 2003.

8 Buku ini telah diterjemahkan beberapa kali dalam bahasa Indonesia, tetapi yang paling baik dan mudah dipahami oleh pembaca adalah yang diterjemahkan oleh Achmad Fawaid, dengan judul Orientalisme: Menggugat Hegemoni Barat dan Mendudukkan Timur Sebagai Subjek (Yogyakarta: Pustaka Pelajar, cet-I, 2010). 


\section{STUDI AL-QUR'AN DI BARAT}

Menurut Fazlur Rahman, (1332-1408 H/1919-1988 M), literaturliteratur Barat modern yang mengkaji Al-Qur’an bisa dibagi menjadi tiga; Pertama, Karya-karya yang berusaha mencari pengaruh YahudiKristen di dalam Al-Qur'an (work that seek to trace the influence of Jewish or Christian ideas on the Qur'ann). Kedua, Karya-karya yang membahas rangkaian kronologis ayat-ayat Al-Qur'an (work that attempt to reconstruct the chronological order of the Qur'ann). Ketiga, Karya-karya yang menjelaskan keseluruhan atau aspek-aspek tertentu dari Al-Qur'an (work that aim at describing the content of the Qur'an, either the whole or certain aspects). ${ }^{9}$ Dalam kasus penelusuran pengaruh Yahudi-Kristen dalam al-Qur'an, beberapa orientalis ingin membuktikan bahwa Al-Qur'an sangat terpengaruh oleh tradisi agama Yahudi atau Kristen, dan Muhammad merupakan penganut salah satu agama tersebut. Bahkan sebagian orientalis mengatakan bahwa Muhammad merupakan salah satu murid kalangan Yahudi.

\section{PENERJEMAHAN AL-QUR'AN}

Kajian Al-Qur'an mulai menggema di dunia Barat setelah munculnya beberapa terjemahan yang dilakukan oleh beberapa kalangan Orientalis. Kajian sarjana Barat terhadap Al-Qur'an dimulai sejak abad ke-12 dengan diterjemahkannya Al-Qur'an ke dalam bahasa Latin oleh Peter the Venerable (w. 1156) dan Abbot of Cluny. Terjemahan ini kemudian disempurnakan oleh Robert of Ketton atau Robert of Chester (w. 1157) pada tahun 1143. Setelah selesai diterjemahkan baru kemudian diterbitkan untuk pertama kalinya pada tahun $1543 \mathrm{M} .{ }^{10}$ Terjemahan inilah yang menjadi cikal bakal lahirnya

9 Fazlur Rahman, Major Themes of the Qurän (Minneapolis: Bibliotheca Islamica, 1989), hlm. xii.

10 Hartmut Bobzin, "Pre-1800 Preoccupations of Quranic Studies", dalam Jane Dammen McAuliffe (ed), Encyclopedia of the Qur'an, Vol-4 (Leiden-Boston: E.J. Brill, 2004), hlm. 
berbagai macam terjemahan Al-Qur'an ke dalam bahasa Eropa. Paling tidak terjemahan Robert of Ketton telah menginspirasi banyak kalangan sarjana Barat (western scholars) untuk mengkaji al-Qur'an.

Terjemahan Al-Qur'an dalam bahasa Latin kedua dilakukan oleh Pendeta Italia, Ludovico Marracci (1612-1700) denga mesin cetak. Hasil terjemahannya kemudian diringkas oleh seorang Yahudi beragama Kristen, Christian Reineccius (1668-1752). Edisi ini hanya menerbitkan teks Latinnya saja dengan menambahkan beberapa catatan yang dianggap penting. Ukuran terbitan Reineccius relatif kecil, yaitu seukuran saku supaya mudah dibawa ke mana-mana. Meskipun kecil, tetapi isinya sangat padat dan berguna bagi para teolog atau sarjana lain yang tidak bisa membaca Al-Qur'an dalam bahasa aslinya, yaitu Arab. ${ }^{11}$

Terjemahan Al-Qur'an dalam bahasa Latin biasanya digunakan untuk tujuan misionaris, seperti yang dilakukan oleh Archbishop Don Rodrigo Jimenez de Rada (1170-1247), Cardinal Juan de Segovia (w. 1458), seorang sarjana besar dari Spanyol. Enea Silvio Piecolomini (kemudian menjadi Paus Pius II) menerjemahkan Al-Qur’an dengan bantuan seorang Muslim ke dalam bahasa Castalian, kemudian ke bahasa Latin. Terjemahan ini dikenal dengan sebutan Trilinggual alQur'an. $^{12}$

Bibliander, seorang tokoh Gereja yang pernah berkunjung dan menjadi anggota delegasi Austria di Ibu Kota Kesultanan Oman tahun 1576-1581 juga pernah menerjemahkan al-Qur'an. Ia menemukan naskah Al-Qur'an kemudian diterjemahkan ke dalam bahasa Jerman yang beredar tahun 1616. Isi atau materi terjemahan Biblander

238. Abdullah Saeed, The Quran: An Introduction (London and Yew York: Routledge, cet-I, 2008), hlm. 122 dan 125. Lihat juga Faisal Ismail, Paradigma Kebudayaan Islam: Studi Kritis dan Analisis (Yogyakarta: SUKA Press, cet-V, edisi revisi, 2004), hlm. 164.

11 Burhanuddin Daya, Kata Pengantar dalam Erwati Aziz, Musykil Al-Qur'an: Kajian Metodologis Penafsiran Ayat-Ayat yang Tampak Kontradiktif tentang Peperangan dan Perkawinan (Yogyakarta: Intan Cendekia, cet-I, 2010), hlm. xiv-xv.

12 Burhanuddin Daya, Kata Pengantar dalam Erwati Aziz, Musykil Al-Qur'an, hlm. xv. 
hampir sama dengan terjemahan bahasa Italia yang ada sebelumnya. Schweigger menilai terjemahan karya Biblander terlalu akademik dan bersifat intelektual, hanya kalangan tertentu saja yang bisa memahaminya. Karena itu, ia menerjemahkan Al-Qur'an sendiri ke dalam bahasa Jerman. Pada tahun 1659, terjemahan Schweigger diterbit ulang dalam format yang lebih besar, dan tahun 1664 diterbitkan lagi untuk ketiga kalinya.

Pada abad ke-18, terjemahan Al-Qur'an langsung dari bahasa Arab dilakukan oleh orientalis Inggris George Sale (m. 1736), yang terbit tahun 1734. Terjemahan ini kemudian diikuti oleh Claude E. Savary (m. 1788) ke dalam bahasa Perancis tahun 1786, dan Friedrich E.S. Boysen (m. 1800) ke dalam bahasa Jerman tahun 1773. Berbeda dengan terjemahan orientalis lainnya, karya Sale yang berjudul The Quran: Commonly Called the Alkoran of Mohammed (London, 1734), masih beredar sampai sekarang dengan 120 edisi. Meskipun banyak dikritik oleh sebagian sarjana Muslim karena mengandung beberapa kesalahan dan kekeliruan penerjemahan, karya tersebut tetap menjadi standar rujukan dalam bahasa Inggris sampai akhir abad ke-19. Perlu diketahui bahwa Sale menulis terjemahan Al-Quran dengan tujuan misionaris.

Banyak sarjana Barat yang telah menerjemahkan Al-Qur'an ke dalam bahasa mereka masing-masing. Sebut saja misalnya, Andrew Arrevabene (Italia, 1547), Johannes Andreas (Aragon, Spanyol, 1500 M), Salomon Schweigger (m. 1622, Jerman, 1616 M), Alexander Ross (Perancis, 1637 M), J.H. Glazemaker atau du Ryer (Belanda, 1658), George Sale (Inggris, 1734 M), Magerlin (Jerman, 1772 M), Claude E. Savary (m. 1788, Perancis, 1783 M, sebagian sumber menyebut tahun 1786), Rodwell (Inggris, 1829 M), Wohl (Jerman, 1826 M), Garsen du Tasi (Perancis, 1840 M), Kasimirski (Jerman, 1840 M), Dr. L. Uhlmann (Inggris, $1880 \mathrm{M}) .^{13}$

13 Aboe Bakar Aceh, Sedjarah al-Quran (Jakarta: Sinar Pudjangga, cet-III, 1952 M), hlm. 
Bobzin menyebutkan bahwa pada akhir abad ke-19 dan awal abad ke-20, terjemahan Al-Qur'an mulai muncul ke dalam bebagai bahasa, seperti Swedia (1843), Italia (1843), Polandia (1849), Ibrani (1857), Rusia (1877), Portugis (1882), dan Spanyol (1907). Beberapa sarjana Barat seperti Richad Bell (m. 1952), Henry Palmer (m. 1882), dan Arthur J. Arberry (m. 1969) mulai menerjemahkan Al-Qur'an sebagai kajian akademik. Menurut Abdullah Saeed, dalam beberapa hal terjemahan Arberry mendapat penilaian positif dari kalangan sarjana Muslim dan non-Muslim. Ini menunjukkan bahwa ia menguasai bahasa Arab dengan baik sehingga menghasilkan pemahaman dan terjemahan yang baik pula.

Selain terjemahan-terjemahan di atas, masih ada lagi terjemahan Al-Qur'an yang kurang dikenal secara luas. Misalnya terjemah Henning (Leipzig, Jerman), Grigull (Halle). Ada juga terjemahan yang tidak lengkap, seperti yang dilakukan oleh Frierech Ruckert, M. Klamroth (Hamburg, Jerman, 1890 M), dan H.L. Fleischer (w. 1888 M). Selain itu, ada juga terjemahan di Barat yang terbit pada abad ke XX. Misalnya, Pickthall (London, Inggris, 1930 M), E.W. Lane, Richard Bell (Edinburgh, Inggris, 1937 M), Grimme (Paderborn, Jerman, 1923 M), Montet (Paris, Perancis, 1923 M). ${ }^{14}$ Selain di Barat, kalangan dunia timur pun tidak ketinggalan untuk menerjemahkan al-Qur'an. Sebutnya misalnya Li Ti Tjin yang menerjemahkan Al-Qur'an ke dalam bahasa Tionghoa. Terjemahan ini pertama kali diterbitkan oleh percetakan Tien Tsin pada tahun 1927. Dengan demikian, terjemahan ini merupakan terjemahan Al-Qur'an yang pertama kali ada dalam sejarah penerjemahan dan percetakan. ${ }^{15}$

Di antara orientalis yang juga memiliki pengaruh besar dalam studi Al-Qur'an adalah Theodor Bibliander (1504-1564). Dia menguasai bahasa Yunani, Hebrew, Syriac, Ethiopic, dan Inggris.

45. Lihat juga Abdullah Saeed, The Qur'an: An Introduction, hlm. 122.

14 Aboe Bakar Aceh, Sedjarah al-Qur'an, hlm. 45.

15 Aboe Bakar Aceh, Sedjarah al-Qur'an, hlm. 45. 
Dengan penguasaan bahasa yang luas inilah, Bibliander mempelajari Al-Qur'an dan menerjemahkannya. Karena tertarik untuk mengkaji Islam, dia menyuruh Johannes Oporin untuk mengirimkan buku-buku yang berbahasa Arab dari Italia. Oporin sendiri merupakan seorang pencetak yang paling penting di Basel (the most important printers at Basle). Pada mulanya percetakan Al-Qur'an dilarang di Basel, dan Oporin dilarang untuk mencetaknya. Tetapi dia mengabaikan seruan tersebut sehingga penerjemahan Al-Qur'an dalam bahasa Latin tetap berjalan.

Sarjana Barat lain yang menentang percetakan Al-Qur'an di Basel adalah Sebastian Munster (1488-1552). Alasan penentangan terhadap percetakan Al-Qur'an adalah karena tidak ada bacaan yang berharga di dalamnya. Dengan kata lain, tidak ada kebenaran sama sekali dalam Al-Qur'an (there is nothing in the Koran which is worth reading: "there is no truth in the Koran"). Pernyataan Munster ini banyak ditentang oleh sarjana-sarjana Barat lainnya. Justru yang tidak ada kebenaran adalah ungkapan Munster sendiri.

Pada abad modern, terjemahan Al-Qur'an yang beredar di dunia Islam secara umum lebih didominasi oleh terjemahan bahasa Inggris. Bahasa ini merupakan bahasa kesatuan dunia karena ia merupakan bahasa internasional. Ada beberapa terjemahan bahasa Inggris yang banyak beredar di dunia Islam termasuk di Indonesia. Di antara penerjemah Al-Qur'an ke dalam bahasa Inggris adalah Muhammad Ali; The Holy Qur'ān: English Translation (Lahore, 1917), Malik Ghulām Farīd; The Holy Quran: English Translation \& Commentary (Pakistan: The Oriental and Religious Publishing Corporation Ltd, cet-I, 1969 M).Mohammed Marmaduke Pickthall; The Meaning of the Glorious Koran: An Explonatory Translation (London, 1930, Delhi: World Islamic Publications, cet-III, $1981 \mathrm{M}$ ).

Kemudian ada Abdullah Yūsuf Alī; The Meaning of The Holy Qur'än: Complete Translation with Selected Notes (Lahore, 1934, Kuala Lumpur-Malaysia: Islamic Book Trust, cet-I, 1996). Abdul Majid 
Daryabadi, The Holy Quran: With English Translation and Commentary (Lahore; 1943), Sher Ali; The Holy Qur'an (Lahore, 1955), Arthur J. Arberry; The Koran Interpreted (London, 1955), N.J. Dawood; The Koran (London, 1956), Abul A'la al-Maududi; The Meaning of the Quran (Lahore, 1967), ${ }^{16}$ Zafrullah Khan, The Quran: Arabic Text and English Translation (London, 1970), Muhammad Muhsin Khan dan Taqìyuddīn al-Hilālī, Explanatory Translation of the Meaning of the Holy Quran (Chicago, 1977), Muhammad Asad, The Message of the Quran (Gibraltar, 1980), M.H. Syakir, Holy Qur'an (New York, 1982), Ahmad Ali, Al-Quran: A Contemporary Translation (Karachi, 1984), Ahmad Zidan dan Dina Zidan,Translation of The Glorious Qur'an, (Kuala Lumpur-Malaysia, A.S. Noordeen, cet-I, 1991 M), dan lain-lain.

Terjemahan Al-Qur'an bahasa Inggris abad ke-18 yang masih populer dan dipakai di kampus-kampus akademik keislaman adalah The Holy Qur'ān: Transliteration in Roman Script, karya M.A. Haleem Eliasii. Diterjemahkan oleh Abdullah Yusuf Ali (New Delhi: Kitab Bhavan, 1784. Edisi Revisi tahun 1996). Selain itu, Al-Qur'an terbitan Arab Saudi yang banyak beredar di tanah air sudah diterjemahkan ke dalam bahasa Inggris oleh Muhammad Taqiyuddīn al-Hilālī dan Muhammad Muhsin Khān dengan judul Translation of the Meaning of The Noble Quran in the English Language.

\section{PENGARUH YAHUDI-KRISTEN TERHADAP AL-QUR'AN}

Pada tahun 1832, University of Bonn di Jerman mengadakan 'sayembara' untuk mencari tulisan terbaik terkait dengan Al-Qur'an dan hukum Islam yang memiliki kaitan dengan tradisi Yahudi. Dalam konteks sekarang, 'sayembara' itu bisa disebut dengan call for paper dengan tema besar 'An Enquiry into those Sources of the Qurān, that is,

16 Sebenarnya edisi ini merupakan terjemahan dari kitab Tafhìm al-Qurān, jadi ia bukan karya asli yang berbahasa Inggris. 
the Muhammadan Law, which were Derived from Judaism'. Pemenang call for paper tersebut adalah Abraham Geiger yang menulis artikel dengan bahasa Latin, kemudian diterbitkan di Jerman dengan judul Was hat Mohammed aus dem Judenthume aufgenommen? pada tahun 1833. Buku ini tidak hanya membuktikan kemiripan ajaran Nabi dan Al-Qur'an dengan tradisi Yahudi, tetapi juga tradisi Kristen. ${ }^{17}$ Bagi Geiger,Al-Qur'an bukan merupakan kalam Ilahi tetapi tidak lebih dari ungkapan manusia biasa.

Theodor Nöldeke berpendapat bahwa banyak kekeliruan dalam Al-Qur'an karena "kebodohan Muhammad" tentang sejarah awal agama Yahudi dan beberapa aspek yang sangat terpengaruh oleh agama tersebut. ${ }^{18}$ Salah satu sarjana Barat yang mengklaim pengaruh Yahudi terhadap Al-Qur'an adalah John Wansbrough (w. 2002) ${ }^{19}$ dalam buku Quranic Studies: Sources and Methods of Scriptural Interpretation(1977). Ia mengatakan bahwa Al-Qur'an (bahkan hadis) berasal dari hasil kontroversi sektarian Yahudi-Kristen dalam kurun waktu lebih dari dua abad. Hal tersebut secara fiktif diproyeksikan sebagai temuan orisinal bangsa Arab. Bahkan ia mengatakan bahwa "doktrin ajaran Islam secara umum, bahkan ketokohan Muhammad, merupakan bentuk pengaruh kependetaan agama Yahudi. ${ }^{20}$

17 Andrew Rippin, "Westren Scholarship and the Qurān", dalam Jane Dammen McAuliffe (ed), The Cambridge Companion to The Qurän (Cambridge: Cambridge University Press, cet-I, 2006), hlm. 239. Reuven Firestone, “The Qur'an and the Bible: Some Modern Studies of Their Relationship", dalam Bible and Qurän: Essays in Scriptural Intertextuality, ed. John C. Reeves, hlm. 7 Abraham Geiger merupakan orang pertama yang menggunakan metode kritik Bibel untuk mengkaji Al-Qur'an. Dia mengkaji Al-Qur’an dengan berangkat dari premis-premis Yahudi dan pendapat bahwa Al-Quran mengambil materi syariatnya dari prinsip-prinsip agama Yahudi. Fahmi Salim, Kritik Terhadap Studi Al-Quran Kaum Liberal (Jakarta: Perspektif, cet-I, 1431 H/2010 M), hlm. 190.

18 M.M. al-A'żamī, The History of The Qur'ānic Text From Revelation to Compilation: A Comparative Study with the Old and New Testament, Sejarah Teks Al-Qur'an dari Wahyu sampai Kompilasi: Kajian Perbandingan dengan Perjanjian Lama dan Perjanjian Baru, trj. Sohirin Solihin, dkk Jakarta: Gema Insani Press, cet-III, 1429 H/2008 M), hlm. 341.

19 Ia merupakan sarjana Yahudi yang pernah menjabat sebagai Guru Besar dalam tafsir alQur'an di School of Oriental and African Studies (SOAS) University of London.

20 R. Stephen Humphreys, Islamic History: A Framework for Inquiry (Princeton: Princeton 
Dalam buku The Original Sources of The Qur'an karya Clair Tisdall, jelas sekali terlihat bahwa secara umum sarjana Barat atau orientalis berpendapat bahwa Al-Qur'an terpengaruh oleh budaya luar Islam. Isi buku tersebut adalah tentangInfluence of Ancient Arabian Beliefs and Practices, Influence of Christianity and Christian Apocryphal Books, Zoroastrian Elements in the Qurian and Traditions of Islam, The Hanifs and Their Influence Upon Nascent Islam. Tisdall mengatakan bahwa "Muhammad tampaknya mendapatkan sedikit dari apa yang diketahui tentang Tuhan kita dan Nabi-Nabi-Nya dari sumber-sumber yang sangat tidak dapat diandalkan. Kita akan lihat bahwa kesamaan perincian antara apa yang diceritakan Al-Qur'an tentang subjeksubjek ini dan apa yang bisa ditemukan dalam literatur apokrifal dan heretikal sangatlah luar biasa. Muhammad tampaknya memiliki bakat yang hebat untuk menolak yang benar dan menerima yang salah sebagaimana dalam kasus tradisi-tradisi Yahudi". ${ }^{21}$

Selain itu, sebagian sarjana Barat juga meneliti tentang asal usul teks al-Qur'an, seperti Gunter Luling, John Wansbrough (1928-2002), Michael Cook, dan Patricia Crone. Selain membahas tentang otentisitas al-Qur'an, kalangan Orientalis juga membahas isu-isu tentang pengaruh

University Press, 1991). Hal ini sebagaimana dikutip oleh M.M. al-A'zamī, The History of The Qur'änic Text From Revelation to Compilation, hlm. 341. Lihat juga, Taufik Adnan Amal, Islam dan Tantangan Modernitas: Studi atas Pemikiran Hukum Fazlur Rahman (Bandung: Mizan, cet-V, 1414 H/1994), hlm. 139. Salah satu sarjana Muslim yang membantah pendapat Wansbrough adalah Fazlur Rahman. Buku Major Themes of the Qur'an merupakan salah satu bentuk respon Rahman terhadap Wansbrough, sebagaimana dikatakan Rahman "my disagreements with Wansbrough are so numerous that they are probably best understood only by reading both this book and his" (ketidaksetujuan saya terhadap Wansbrough demikian banyak, sehingga hanya mungkin dipahami dengan tepat jika membaca buku [saya] ini dan bukunya) Fazlur Rahman, Major Themes of The Qurān (Minneapolis: Bibliotheca Islamica, 1989), hlm. xiv.

21 Louay Fatoohi, The Mystery of The Historical Jesus: The Messiah in the Qur'an, the Bible, and Historical Sources (Birmingham: Luna Plena Publishing, 2007), telah diterjemahkan ke dalam bahasa Indonesia oleh Yuliani Liputo dengan judul The Mystery of Historical Jesus: Sang Mesias Menurut Al-Qur'an, Alkitab, dan Sumber-Sumber Sejarah (Bandung: Mizan, cet-I, 2013), hlm. 53. 
Yahudi, Kristen, atau agama lainnya terhadap al-Quran. Perlu diketahui bahwa menurut Edwad W. Said, Patricia Crone telah meneliti Islam (al-Qur'an, hadis, dan lain-lain) dan kaum Muslim tanpa membekali dirinya dengan pengetahuan memadai tentang Islam (Islamic Studies).

Bahkan menurut R.B. Serjeant, pengetahuan Crone tentang bahasa Arab tidak cukup dalam memahami teks-teks Arab yang menggambarkan Islam dan umat Islam. Tidak heran jika pandanganpandangannya tentang kajian Islam dan umat Islam sangat tidak mendasar dan tidak akurat (baseless and inaccurate). ${ }^{22}$ Kalau pendapat ini benar, kemungkinan besar Crone hanya menggunakan literaturliteratur berbahasa Arab yang sudah diterjemahkan ke dalam bahasa Inggris atau bahasa lainnya. Meskipun demikian, hal itu tidak menjadi masalah selama terjemahan yang dipakai bisa dipertanggungjawabkan secara ilmiah akademik.

Dalam kaitannya dengan studi asal-usul atau pengaruh YahudiKristen terhadap Al-Qur'an, kalangan Orientalis banyak menerbitkan buku. Sebut saja misalnya, Was hat Mohammed aus den Judentum aufgenommen (Abraham Geiger), The Origins of the Qur'an: An Inquiry into the Sources of Islam (W. Goldsack), The Original Sources of The Qur'an (W.st. Clair Tisdall), The Jewish Foundation of Islam (Charles Torrey), Judaism in Islam, Biblical and Talmudic Background of the Koran and its Commentaries: Suras II and III (Abraham Isaac Katsh), The Jewish Origins of the Qur'an 18:65-82? Reemaxining Arent Jan Wensinsk's Theory (Brannon M. Wheeler), The Spiritual Background of Early Islam: Studies in Ancient Arab (M.M. Bravmann), Hanafiyya and Ka'ba: An Inquiry into the Arabian Pre-Islamic Background of Din Ibrahim (Uri Rubin), Hagarism: The Making of Islamic World (Patricia Crone dan Michel A. Cook), Roman, Provincial and Islamic Law: The Origins of the Islamic Patronate (Patricia Crone).

22 Akh. Minhaji, Sejarah Sosial dalam Studi Islam: Teori, Metodologi dan Implementasi, edisi revisi (Yogyakarta: Suka Press, cet-II, 2013), hlm. 119-120. 
Meskipun demikian, banyak juga sarjana Barat-Kristen yang mengkaji Al-Qur'an secara serius sehingga mereka memiliki kesimpulan bahwa Al-Qur'an memang kalam Ilahi dan merupakan mukjizat. Sarjana Katolik-Kristen yang juga banyak mengkaji AlQur'an adalah Issa J. Boullata. ${ }^{23}$ Dia menguasai bahasa Arab dan bahasa Inggris, bahkan pernah menyempatkan diri memberi kuliah-kuliah dalam bidang I'jāz al-Qur'ān pada Program Pascasarjana IAIN Syarif Hidayatullah Jakarta (sekarang UIN). Salah satu buku Boullata yang telah diterjemahkan ke dalam bahasa Indonesia adalah I'jāz al-Qur'ān al-Karīm 'Abara al-Tārīkh, dengan judul Al-Qur'an yang Menakjubkan: Bacaan Terpilih dalam Tafsir Klasik hingga Modern dari Seorang Ilmuan Katolik. Edisi Indonesia ini diberi kata pengantar oleh Mufassir Indonesia, M. Quraish Shihab. ${ }^{24}$

23 Issa J. Boullata dilahirkan di Yerusalem, menyelesaikan Ph.D. dalam bidang sastra Arab di University of London pada 1969. Dari tahun 1968-1975 dia mengajar di Hartford Seminary, Connecticut. Pada 1975 dia bergabung dengan McGill University, Montreal, Canada, sebagai profesor bahasa dan sastra Arab di Institute of Islamic Studies. Boullata juga memberikan kursus bahasa Arab, menggagas dan menyelenggarakan sejumlah seminar tentang sastra Arab, pemikiran Arab modern, dan kajian al-Qur'an. Dia juga menjadi pembimbing dan penguji tesis dan disertasi yang membahas topik-topik tersebut. Boullata pernah menjabat sebagai Direktur The McGill-Indonesia Project pada 1993-1995. Dia pensiun pada 1 Januari 1999 tetapi masih mengajar paruh waktu di McGill sampai pensiun penuh pada tahun 2004. Di antara karya-karya Boullata yang dipublikasikan adalah Outlines of Romanticism in Modern Arabic Poetry (1960), Badr Syakir al-Sayyab: His Life and Poetry (1971), kedua dalam bahasa Arab yang diterjemahkan ke dalam bahasa Inggris. Sedangkan bukunya dalam bahasa Inggris, Trends and Issues in Contemporary Arab Tought (1990), dan labih dari 80 artikel serta 250 lebih resensi yang dimuat dalam jurnal-jurnal ilmiah. Pada tahun 2000 , sebuah buku telah diterbitkan untuk menghormati, menghargai dedikasi dan jasa-jasa Boullata oleh E.J. Brill di Netherland. Buku itu berjudul Tradition, Modernity, and Postmodernity in Arabic Literature: Essays in Honor of Professor Issa J. Boullata. Editor buku ini adalah Kamal Abdel Malek dan Wael B. Hallaq. Di dalamnya terdapat 20 sarjana yang sebagian besar merupakan kolega dan murid-murid pertama Boullata yang menyumbangkan tulisan. Boullatta juga menjadi editor buku Literary Structures of Religious Meaning in the Quran (London: Curzon Press, 2000).

24 Issa J. Boullata, Al-Quran yang Menakjubkan: Bacaan Terpilih dalam Tafsir Klasik hingga Modern dari Seorang Ilmuan Katolik, trj. Tim Penerjemah Lentera Hati (Jakarta: Lentera Hati, cet-I, 1429 H/2008 M). 
Harus diakui bahwa sedikit atau banyak, isi ajaran Al-Qur'an memang ada beberapa kemiripan dengan kitab-kitab terdahulu. Sebelum terjadi penyimpangan dalam Taurat dan Injil, ajaran-ajaran Nabi Musa dan Isa masih belum tercampur dengan pemikiran manusia. Tetapi setelah beberapa generasi, Al-Qur'an mengabarkan bahwa kaum Yahudi dan Nasrani telah melakukan penyimpangan terhadap ajaran agama yang dibawa Nabi mereka. ${ }^{25}$ Camilia Adang telah mengkaji pandangan-pandangan beberapa ulama abad pertengahan terhadap kaum Yahudi dan kitab suci mereka. Dia mengkaji pengetahuan ulamaulama Islam tentang Taurat dan menganalisis beberapa isu. Termasuk klaim bahwa Taurat memuat penjelasan tentang Nabi Muhammad dan penjelasan tersebut telah dirubah ataupun dihilangkan. ${ }^{26}$ Salah seorang sarjana Barat yang bernama Kenneth Cragg berpendapat bahwa memang ada kesamaan kitab suci umat Islam dan Nasrani. Cragg secara khusus melihat relevansi kesamaan terletak pada isu tentang kehendak Tuhan dalam menciptakan perintah dan pengambilalihan perintah ini kepada manusia. ${ }^{27}$

Dalam artikel yang berjudul "The Charge of Distortion of Jewish and Christian Scripture", ${ }^{28}$ Abdullah Saeed mengkaji tesis yang mengatakan bahwa kitab suci yang dimiliki kaum Yahudi dan Nasrani

25 F. E. Peters telah melakukan perbandingan terhadap teks Yahudi, Nasrani, dan Islam, yang difokuskan pada isu-isu tentang 'Anak-anak Ibrahim'. Masing-masing volume dari bukunya, Peters menjelaskan sumber-sumber kitab suci, teolog, pendeta, penguasa, dan berbagai aturan. Di antara topik pembahasannya adalah tentang kenabian, pandangan tentang gereja dan negara, interpretasi kitab suci dan hukum, kemudian aspek ritual dan spiritualF.E. Peters, Judaism, Christianity and Islam: The Classical Texts and Their Interpretation; Volume I: From Covenant to Community, Volume II, The Word and the Law and the Poeple of of God, Volume III, The Work of the Spirit (Princeton: Princeton University Press, 1990).

26 Camilia Adang, Muslim Writers on Judaism and the Hebrew Bible From Ibn Rabban to Ibn Hazm (Leiden: Brill, 1996).

27 Kenneth Cragg, A Certain Sympathy of Scriptures: Biblical and Quranic (Brighton: Sussex Academic Press, 2004)

28 Abdullah Saeed, "The Charge of Distortion of Jewish and Christian Scripture", The Muslim World, Fall 2002, 92 (3/4), hlm. 419-436. 
telah lama diselewengkan dan dirubah. Karena itu, ia tidak bisa lagi dijadikan sebagai dasar Firman Tuhan. Saeed juga mendiskusikan isuisu tentang distorsi dan kesulitan-kesulitan yang dialami oleh sarjana atau ulama Muslim dalam bidang ini. Saeed sendiri telah membahas hubungan Al-Qur'an dengan kitab suci agama lain (The Qur'an and Other Scriptures) dalam bukunya The Qur'an: An Introduction (London-New York: Routledge, 2008). ${ }^{29}$ Hal serupa juga dilakukan oleh Mun'imSirry dalam bukunya, Polemik Kitab Suci: Tafsir Reformis Atas Kritik Al-Qur'an terhadap Agama Lain, trj. R. Cecep Lukman Yasin(Jakarta: PT Gramedia Pustaka Utama, 2013).

Beberapa sarjana Muslim keberatan dengan pendapat beberapa orientalis yang mengatakan bahwa gagasan dan konsep agama atau ajaran Islam merupakan pinjaman atau jiplakan dari tradisi Judio-Kristen. Kalaupun ada kesamaan maka hal itu sangat wajar karena agama atau ajaran Nabi-nabi terdahulu berasal dari satu sumber sebelum dirubah oleh pemeluk-pemeluknya. Sebagai agama terakhir, tentu Islam yang berlandaskan Al-Qur'an sangat wajar jika ada kemiripan dengan agama-agama sebelumnya. Justru sebelum munculnya agama Yahudi dan Kristen, peradaban Mesopotamia sudah diwarisi dalam lingkungan Arab.

\section{KAJIAN KRITIS TERHADAP AL-QUR'AN}

Selain mengkaji Al-Qur'an, beberapa sarjana Barat juga menilai Al-Qur'an sebagai penuh kepalsuan karena merupakan karya Nabi Muhammad sendiri. Pada abad ke-16, seorang Guru Besar dari Gereja Protestan bernama Antonius Waleus, mengatakan bahwa Al-Qur'an bukan kitab suci, kitab palsu, penuh kontradiksi. Isinya penuh dengan dongeng-dongeng yang diceritakan Muhammad. Al-Qur'an hanya

29 Buku ini telah diterjemahkan ke dalam bahasa Indonesia oleh Shulkhah dan Sahiron Syamsuddin dengan judul Pengantar Studi Al-Qur'an (Yogyakarta: Baitul Hikmah Press, cet-I, 2016, cet-II, 2018). 
pantas didengarkan oleh anak-anak, itu sebabnya Al-Qur'an tidak dapat dipercaya. Antonius yang lahir pada tahun 1573, pernah mendirikan Sekolah Tinggi Agama Kristen, Seminarium Indicum. Sekolah ini didirikan di Belanda, dan dia sendiri menjadi Direkturnya selama 10 tahun (1622-1632). Pendapat Antonius diikuti oleh Gilbertus Voitus (1586-1676), yang merupakan seorang Guru Besar teologi di Utrecht. ${ }^{30}$

Antonius dan Gilbertus bukanlah penghujat pertama terhadap al-Qur'an, karena sebelumnya sudah dilakukan oleh Theophanes the Confessor. Ia merupakan seorang pastur dan imam penerima pengampunan dosa serta pertobatan yang lahir tahun $813 \mathrm{M}$. Teolog yang semasa dengan Theophanes adalah John of Damascus dan Nicates of Bizantium. Mereka menuduh Nabi Muhammad menderita penyakit epilepsi, bermasalah dengan isteri-isterinya, Khadijah telah mengangkat derajattnya dari seorang kampungan sehingga bermartabat dengan mengawininya, ajaran-ajarannya adalah penyembahan terhadap berhala, setan, dan perdukunan. ${ }^{31}$ Masih banyak lagi hujatan mereka terhadap Al-Qur'an dan Nabi Muhammad.

Bergstrasser, Jeffery dan Pretzl pernah berencana untuk membuat edisi kritis terhadap al-Qur'an, tetapi rencana mereka gagal setelah bahan-bahan yang mereka kumpulkan hancur karena terkena bom pada Perang Dunia II. Informasi ini diberikan sendiri oleh Arthur Jeffery dalam bukunya Materials for the History of the Text of the Qur'an: The Old Codices. A. Jeffery mengakui Al-Qur'an sebagai kitab suci meskipun ia bersifat kritis sebagaimana terlihat dalam tulisannya The Quran as Scripture. ${ }^{32}$ Kajian yang dilakukan Arthur sangat luas, ia juga

30 Burhanuddin Daya, Pergumulan Timur Menyikapi Barat: Dasar-Dasar Oksidentalisme (Yogyakarta: Suka Press, cet-I, 2008), hlm. 5-6. Burhanuddin Daya juga mengutip hal ini dalam Kata Pengantar terhadap buku Erwati Aziz, Musykil Al-Quran: Kajian Metodologis Penafsiran Ayat-Ayat yang Tampak Kontradiktif tentang Peperangan dan Perkawinan (Yogyakarta: Intan Cendekia, cet-I, 2010), hlm. xvi.

31 Burhanuddin Daya, Kata Pengantar dalam Erwati Aziz, Musykil Al-Quran, hlm. xvi-xvii.

32 Informasi ini bisa juga dilihat dalam Gerd-R. Puin, "Observation on Early Qur'an Manuscripts in Șan'ā, dalam Stefan Wild (ed), The Qur'an As Text (Leiden: E.J. Brill, 
mengkaji kosa kata-kosa kata asing yang terdapat dalam Al-Qur'an (the foreign vocabularies in the Qur'an)..$^{33}$ Hal serupa juga dilakukan oleh Michael Carter dalam artikelnya "Foreign Vocabulary (Kosa Kata yang Asing)" $\cdot{ }^{34}$ Carter hanya mengulang apa yang dijelaskan oleh Jeffery dan Luxenberg yang mengatakan bahwa memang ada beberapa kosa kata Al-Qur'an yang bukan asli bahasa Arab.

Menurut sebuah sumber yang dapat dipercaya, Luxenberg merupakan seorang warga negara Jerman yang berkebangsaan Libanon, penganut Kristen. Ia memperoleh M.A. dan Dr.Phil. dalam bidang Arabistik. Pada tanggal 28 Mei 2003 ia sempat diundang memberikan ceramah di Universitat des Saarlandes tantang "Pengaruh Bahasa Aramaik terhadap Bahasa Al-Qur'an" (Der Einfluss des Aramaischen auf die Sprache des Korans). Di samping sebagai dosen, Luxenberg juga aktif menulis dan memberikan wawancara untuk media masa. Di antara bukunya adalah "Cara Membaca Al-Qur'an dengan Bahasa Syro-Aramaik: Sebuah Sumbangsih Upaya Pemecahan Kesukaran Memahami Bahasa Al-Qur'an" (Die syro-aramaische Lesart des Koran Ein Beitrag zur Entschlusselung der Koransprache, yang diterjemahkan ke dalam bahasa Inggris oleh Verlag Hans Schiler dengan judul The Syro-Aramaic Reading of the Koran: A Contribution to the Decoding of the Language of the Koran).

Buku tersebut banyak menarik perhatian cendekiawan Muslim setelah dipublikasikan oleh beberapa media massa, terutama sekali mereka yang menggeluti studi Al-Qur'an. Newsweek edisi 28 Juli 2003,

1996), hlm. 107. Arthur Jeffery, Materials for the History of the Text of the Qur'an (AMS Press, New York, United States of America. 1975. (E.J. Brill, 1937). Buku ini pada awalnya merupakan ceramah Arthur Jeffery yang disampaikan pada tanggal 31 Oktober 1946 pada pertemuan The Middle East Society of Jerusalem, Israel. Ceramah tersebut berjudul “The Textual History of the Qur'an". Lihat juga M.M. al-A'zamī, The History of The Qurānic Text From Revelation to Compilation, hlm. 337.

33 Arthur Jeffery, The Foreign Vocabulary of The Qur'ann, ed, Gerhard Bowering dan Jane Dammen McAuliffe (Leiden-Boston: Brill, 2007).

34 Lihat Michael Carter, "Foreign Vocabulary", dalam Andrew Rippin (ed), The Blackwell Companion to The Qurān (USA: Blackwell Publishing, 2006), hlm. 120-139. 
melansir tulisan berjudul Challanging the Quran. Artikel ini ditulis oleh Stefan Wild yang kemudian memicu kontroversi, pada akhirnya majalah itu dilarang beredar di Pakistan. Di Indonesia, masalah ini menjadi ramai setelah majalah GATRA menampilkannya sebagai cover story pada No. 37 edisi 4 Agustus 2003.

Luxenberg berani mengklaim bahwa: (a). Bahasa Al-Qur'an sebenarnya bukan bahasa Arab. Itulah sebabnya banyak kata-kata dan ungkapan yang sering dibaca keliru atau sukar dipahami. Untuk memahaminya harus merujuk pada bahasa Syro-Aramaik yang konon merupakan lingua franca pada masa itu. (b). Bukan hanya kosa kata Al-Qur'an yang berasal dari Syro-Aramaik, tetapi juga isi ajarannya pun diambil dari tradisi kitab Yahudi dan Kristen Syria. (c). Al-Qur'an yang ada sekarang tidak otentik, perlu ditinjau kembali dan diedit ulang. ${ }^{35}$

Kesimpulan kajian Luxenberg tidaklah berbeda dengan kajian orientalis-missionaris Kristen lainnya. Intinya mereka menggugat Al-Qur'an sebagai wahyu yang diturunkan Allah swt. kepada Nabi Muhammad saw. Al-Qur'an tidaklah tanzil (turun), suci, dan bebas dari kesalahan sebagaimana ditegaskan dalam Al-Qur'an (Q.S. 15: 9). Menurut Luxenberg -dengan melakukan kajian semantik terhadap sejumlah kata dalam Al-Qur'an yang diambil dari perbendaharaan bahasa Syiriac-Al-Qur'an yang ada saat ini adalah salah salin dan berbeda dengan teks aslinya. Teks asli Al-Qur'an lebih mirip bahasa Aramaic daripada bahasa Arab, dan naskah asli itu telah dimusnahkan oleh khalifah 'Uśmān bin 'Affān (w. 35 H). Pendapat-pendapat Luxenberg banyak dibantah oleh Angelika Neuwirth.

Hal ini tidak asing bagi orang yang bergelut dalam studi Al-Qur'an atau Ulumul Qur'an. Sebagian sarjana Muslim memang mengakui bahwa ada bahasa selain Arab yang diserap oleh al-Qur'an. Dalam

35 Dikuip dari Syamsuddin Arif, Orientalis \& Diabolisme Pemikiran (Jakarta: Gema Insani Press, cet-I, 1429 H/2008 M), hlm. 17. Fahmi Salim, Kritik Terhadap Studi Al-Quran Kaum Liberal (Jakarta: Perspektif, cet-I, 1431 H/2010 M), hlm. 200-201. 
istilah Ulumul Qur'an disebut dengan arab musta'rabah, bahasa nonArab yang diserap ke dalam bahasa Arab karena terjadi interaksi antara orang Arab dengan masyarakat sekitarnya. Jika demikian, maka apa yang dilakukan oleh Arthur Jeffery dan yang mengikutinya tidak ada masalah. Ini disebabkan karena hal tersebut juga diakui oleh sebagian sarjana Muslim sendiri.

Pada tahun 1927, Alphonse Mingana, pendeta Kristen asal Irak dan guru besar di Universitas Brimingham Inggris, mengumumkan bahwa "the time has surely come to subject the text of the Koran to the same criticism as that to which we subject the Hebrew and Aramic of the Jewish Bible, and the Greek of the Christian scriptures (sudah tiba saatnya sekarang untuk melakukan kritik teks terhadapa Al-Qur'an sebagaimana yang telah kita lakukan terhadap kitab suci Yahudi yang berbahasa Ibrani-Arami dan kitab suci Kristen yang berbahasa Yunani). ${ }^{36}$ Dengan adanya seruan ini maka kajian terhadap kitab suci mulai digalakkan dalam lingkungan Kristen, yang kemudian berimbas kepada studi al-Qur'an. Kalangan Orientalis banyak menulis artikel dalam berbagai bahasa yang dikumpulkan dalam satu buah buku dengan beberapa penulis.

Kajian kritis terhadap Al-Qur'an lebih dilatarbelakangi oleh kekecewaan beberapa sarjana orientalis atau Islamist (baca Kristen) terhadap kitab suci agama mereka (Bibel). Banyak di antara mereka yang mengeluh terhadap ragam versi Bibel yang ditulis oleh beberapa sarjana Kristen sendiri. Mereka terpaksa menerima kenyataan pahit bahwa Bibel yang ada di tangan mereka sekarang ini terbukti tidak asli atau palsu. Ini disebabkan karena terlalu banyak campur tangan penulis di dalamnya, sehingga sulit untuk dibedakan mana yang wahyu dan mana yang bukan. ${ }^{37} \mathrm{Hal}$ ini sebagaimana ditegaskan oleh Kurt Aland dan Barbara Aland dalam buku The Text of the New Testament:

36 Syamsuddin Arif, Al-Qur'an, "Orientalisme dan Luxenberg", dalam Al-Insan; Jurnal Kajian Islam, Al-Qur'an dan Serangan Orientalis, Vol-I, No. I, Januari 2005, hlm. 9-10. Lihat juga dalam bukunya Syamsuddin Arif, Orientalis \& Diabolisme Pemikiran, hlm. 3.

37 Syamsuddin Arif, Orientalis \& Diabolisme Pemikiran, hlm. 3. 
Until the biginning of the fourth century, the text of the new testament developed freely.....Even for later scribes, for example, the parallel passages of the Gospel where so familiar that they would adapt the text of one Gospel to that of another. They also felt themselves free to make corrections in the text, improving it by their own standard of correctness, whether grammatically, stylitically, or more substantively.38

Saint Jerome mengatakan bahwa banyak penulis Bibel yang menulis makna yang dipikirkan, bukan apa yang mereka jumpai sebagaimana aslinya. Ini justru lebih menambah kesalahan terhadap penulisan teks Bibel. ${ }^{39}$ Melihat fenomena ini, Bruce M. Metzger menulis buku dengan judul The Text of the New Testament: Its Transmission, Corruption and Restoration. Demikian juga dengan Manfred Heiligmann yang menulis Ada Apa dengan Alkitab? : Kesalahan, Absurditas, Inkonsitensi dan Vulgaritas dalam Alkitab (Jakarta: Bina Communio, cet-I, 2011).

Selain mengkaji sejarah Al-Qur'an, kalangan Orientalis juga melakukan kajian terhadap sejarah penafsiran al-Qur'an. Semangat baru dalam studi Al-Qur'an (new spirit in Quranic Studies) ini telah melahirkan berbagai macam tulisan di Barat. Buku yang dianggap penting dalam kajian ini adalah Approaches to the History of the Interpretation of the Qur'an (Oxford 1988), yang diedit oleh Andrew Rippin (murid setia John Wansbrough), dan Approaches to the Qur'an (London 1993), diedit oleh G.R. Hawting. Al-Qur'an tidak hanya dikaji dari segi kesejarahan, teks, manuskrip, tetapi juga dikaji dengan membandingkan dengan kitab-kitab suci agama lain (Comparative Studies). Kajian ini tidak hanya ditulis oleh kalangan orientalis saja, tetapi juga oleh sarjana Muslim sendiri. Studi komparasi sebanarnya hanya akan melihat kelebihan dan kekurangan obyek yang dikaji. Sebenarnya tidak perlu dibandingkan karena dari segi sejarah, sumber, teks, bahasa, materi, kitab-kitab di dunia ini berbeda-beda.

38 Syamsuddin Arif, Orientalis \& Diabolisme Pemikiran, hlm. 3-4.

39 Syamsuddin Arif, Orientalis \& Diabolisme Pemikiran, hlm. 4. 
Studi perbandingan terhadap Al-Qur'an dengan Bibel sangat tidak sesuai karena tidak setara. Al-Qur'an dalam Islam setara dengan Isa atau Yesus dalam bahasa Kristen. Adapun Bibel yang merupakan laporan yang ditulis oleh murid-murid Isa maka ia setara dengan hadis yang merupakan laporan sahabat terhadap perkataan, perbuatan, ketetapan, ataupun sifat-sifat Nabi saw. Hal ini tidak bisa direalisasikan karena sudah masuk wilayah keimanan (belief). Dalam Islam,Al-Qur'an berasal dari Allah (Tuhan), sedangkan dalam Kristen yang berasal dari Tuhan adalah Yesus (Isa al-Masih) yang merupakan the Word of God atau the Son of God. Tidak heran jika Harry Wolfson dalam buku The Philosophy of Kalam mengatakan bahwa pentingnya Al-Qur'an bagi Kaum Muslim dan Islam sama pentingnya dengan pentingnya Yesus bagi umat Kristen (the importance of the Qur'an for Muslim and Islam is tantamount to the importance of the person of the Jesust Christ for Christians and christianity. It has been rightly observed that the Christian consept of incarnation correspond to what one might call "illibration" in Islam). ${ }^{40}$

Di sini jelas bahwa Wolfson tidak membandingkan Al-Quran dengan Bibel atau Perjanjian Baru (New Testament) tetapi dengan Yesus sendiri. Dalam tradisi Kristen yang menjadi wahyu adalah Yesus sendiri, dan dalam Islam wahyu itu adalah al-Qur'an. Dengan demikian, studi perbandingan antara Al-Qur'an dan Bibel merupakan kajian perbandingan yang tidak sebanding. Meskipun demikian, banyak sarjana Barat yang melakukan studi perbandingan (comparative study) antara kedua kitab suci tersebut. Ada beberapa literatur yang mengkaji teks Al-Qur'an dari segi bahasa Al-Qur'an sendiri, ataupun dengan kitab-kitab lainnya.

40 Stefan Wild, "We Have Sent Down to Thee the Book with the Truth: Spatial and Temporal Implications of the Qur'anic Concept of Nuzūl, Tanzīl, and Inzāl”, dalam Stefan Wild, ed. The Qur'an As Text (Leiden- New York - Koln: E.J. Brill, 1996), hlm. 137. 
Di antara literatur itu adalah A Comparative Lexical Study of Qur'anic Arabic, karya Martin R. Zammit. ${ }^{41}$ The Bible, The Koran, and The Talmud, karya Gustav Weil. ${ }^{42}$ Buku ini merupakan terjemahan dari bahasa Jerman.The Qur'an and the Gospels: A Comparative Study, karya Muhammad M. Abu Laylah. ${ }^{43}$ Beberapa sarjana Barat telah meneliti hubungan Bibel dan Al-Qur'an, seperti Reuven Firestone dalam artikelnya "The Qur'an and the Bible: Some Modern Studies of Their Relationship”, Vernon K. Robbins dan Gordon D. Newby; “A Prolegomenon to the Relation of the Qur'ān and the Bible", John C. Reeves; "Some Explorations of the Intertwining of Bible and Qur'ān", Brian M. Hauglid; "On the Early Life of Abraham: Biblical and Qur'ānic Intertextuality and the Anticipation of Muhammad", Between Bible and Qur'an: The Children of Israel and the Islamic Self-Image, karya Uri Rubin, ${ }^{44}$ dan lain-lain.”45 Kajian kritis terhadap Al-Qur'an memang sudah banyak dilakukan oleh kalangan orientalis sebagaimana telah dilakukan terhadap Bibel.

Kajian orientalis terhadap Al-Qur'an di Barat memang beragam, bahkan ada juga yang meragukan keotentikan Al-Qur'an. Hal ini sebagaimana dijelaskan oleh Taufik Adnan Amal dalam bukunya Rekonstruksi Sejarah al-Qur'an.Dalam buku Bell's Introduction to The Quran, Montgomery Watt menyebutkan bahwa sarjana Barat yang

41 Martin R. Zammit, A Comparative Lexical Study of Quranic Arabic (Leiden-Boston: Brill, 2002).

42 Gustav Weil, The Bible, The Koran, and The Talmud (London: Longman,Brown, Green, Longmans, 1846)

43 Muhammad M. Abu Laylah, The Qur'an and the Gospels: A Comparative Study (Kairo: Al-Falah Foundation for Translation, Publication \& Distribution, cet-III, 1426 H/2005 M). Pada mulanya buku berbahasa Arab dengan judul al-Qurān wa al-Injīl: Dirāsah Muqāranah.

44 Uri Rubin, Between Bible and Quran: The Children of Israel and the Islamic Self-Image (Princeton: The Darwin Press, 1999).

45 Artikel-artikel ini terkumpul dalam buku Bible and Qurān: Essays in Scriptural Intertextuality, diedit oleh John C. Reeves (Atlanta-USA: Society of Biblical Literature, 2003). 
pertama kali mengemukakan dugaan kepalsuan terhadap beberapa bagian Al-Qur'an adalah Silvestre de Sacy. ${ }^{46}$ Ia merupakan salah seorang orientalis dari Perancis yang meragukan ayat 144 surat Āli 'Imrān yang berbicara tentang kemungkinan wafatnya Nabi Muhammad. Setelah Silvestre meragukan otentisitas beberapa ayat Al-Qur'an, Gustav Weil meragukan ayat ke 185 surat Āli 'Imrān, ayat 35 surat al-Anbiyā, ayat 57 surat al-Ankabūt dan ayat 30 surat al-Zumar. Ayat-ayat tersebut juga berbicara tentang kemungkinan wafatnya Nabi Muhammad. Menurutnya, ayat-ayat tersebut merupakan tambahan dari Abū Bakar sebagai khalifah pengumpul Al-Qur'an untuk pertama kalinya. Untuk menguatkan pendapatnya, Weil mengumpulkan beberapa riwayat tentang wafatnya Nabi Muhammad. ${ }^{47}$

Weil juga meragukan otentisitas ayat 1 surat al-Isrä’ yang mengabarkan tentang perjalanan Nabi Muhammad dari Masjidil Haram (Makkah) ke Baitul Maqdis (Yerusalem). Ia berargumen bahwa hanya satu ayat saja yang berbicara tentang peristiwa Isrä, dan ayat-ayat setelahnya sama sekali memiliki kaitan apapun. Pendapat ini menguatkan pendapat John Wansbrough bahwa Al-Qur'an merupakan kreasi pasca kenabian yang dipengaruhi oleh Yahudi sebagaimana disebutkan di atas. Ayat tentang al-Isrä tersebut bertentangan dengan klaim umum Muhammad sebagai seorang Rasul, bukan sebagai pembuat mukjizat. Weil juga mempermasalahkan ayat 46 surat alHijr, yang menurutnya, beberapa riwayat merujuk kepada Abū Bakar, kemungkinan ayat tersebut direkayasa untuk menghormati khalifah pertama itu. ${ }^{48}$

Hirschfeld, seorang orientalis Jerman juga mempermasalahkan keaslian ayat yang memuat nama Nabi Muhammad, seperti ayat 144

46 Dikutip dari Taufik Adnan Amal, Rekonstruksi Sejarah al-Quran (Yogyakarta: Forum kajian Agama dan Budaya, cet-I, 2001), hlm. 248.

47 Gustav Weil, Historisch-kritische Einleitung in der Koran (Leifzig: Bielefeld, 1878). Taufik Adnan Amal, Rekonstruksi Sejarah al-Qur'an, hlm. 248.

48 Taufik Adnan Amal, Rekonstruksi Sejarah al-Qur'an, hlm. 249. 
surat Āli 'Imrān, ayat 40 surat al-Aḥzāb, dan ayat 29 surat al-Fatḥ. Ayat-ayat ini merupakan interpolasi (penyisipan), bukan bagian dari Al-Qur'an. Dengan bersandar pada pandangan A. Sprenger dan Fr. Bethge, Hirschfeld mengatakan bahwa Muhammad merupakan istilah mesianik, bukan nama yang sebenarnya. ${ }^{49}$ Kajian terhadap otentisitas dan integritas Al-Qur'an juga dilakukan oleh orientalis Perancis, Paul Casanova. Dalam bukunya, Mohammed et la Fin du Monde (19111924). Gagasan Casanova merupakan pengembangan dari beberapa orientalis yang mengatakan bahwa Nabi Muhammad tergerak menjalankan misinya karena terkesan dengan ide pengadilan akhirat.

Casanova memandang bahwa Nabi berada di bawah pengaruh sejumlah sekte Kristen yang sangat menekankan ide tersebut. Pengaruh ini kemudian membentuk tema utama kenabiannya dan merupakan pesan penting tentang konsep ketuhanan yang didakwahkan Nabi. Untuk menguatkan misi kenabiannya, Muhammad memanipulasi Al-Qur'an secara masif untuk menghilangkan doktrin tersebut dari kitab suci. Di kalangan sarjana Barat sendiri, ide-ide Casanova tidak begitu diterima karena kurang didasarkan pada studi mendalam terhadap Al-Qur'an dan beberapa aspek kajian awal Islam. Pernyataanpernyataannya sering menimbulkan misinterpretasi dan kegagalan dalam mengapresiasi perkembangan historis ajaran al-Qur'an. ${ }^{50}$

Sebenarnya pendapat-pendapat orientalis tersebut bisa dikaji secara mendalam dalam literatur-literatur sejarah Al-Qur'an. ${ }^{51}$ Beberapa aspek kajian orientalis telah dibantah oleh M.M. al-A'żamī (w. 1429 H/2017 M), dalam bukunyaThe History of The Qur'ānic Text From Revelation to Compilation: A ComparativeStudy with the Old

49 Taufik Adnan Amal, Rekonstruksi Sejarah al-Quran, hlm. 249.

50 Taufik Adnan Amal, Rekonstruksi Sejarah al-Qur'an, hlm. 249-250.

51 Di antara karya yang membahas sejarah Al-Qur’an adalah karya Ibrāhim Abyārī, Tārīkh al-Qurān,(Kairo: Dār Qalam, cet-1, 1965 M).'Abd al-囚abūr Syāhīn, Tārīkh al-Qurān (Kairo: Dār Qalam, cet-1, 1966) M. Taufik Adnan Amal, Rekonstruksi Sejarah al-Quran (Yogyakarta: Forum kajian Agama dan Budaya, cet-I, 2001), Athaillah, Sejarah al-Quran: Verifikasi tentang Otentisitas al-Quran, (Yogyakarta: Pustaka Pelajar, cet-I, 2010). 
and New Testament, yang diterjemahkan ke dalam bahas Indonesia oleh Sohirin Solihin, Anis Malik Thoha, Ugi Suharto, dan Lili Yulyadi, dengan judul Sejarah Teks Al-Qur'an dari Wahyu sampai Kompilasi: Kajian Perbandingan dengan Perjanjian Lama dan Perjanjian Baru (Jakarta: Gema Insani Press, cet-III, 1429 H/2008 M).

\section{PENUTUP}

Demikianlah tren kajian Al-Qur'an di Barat yang dimulai dari masa kemunculan dan perkembangan hingga masa polemik. Sejarah kajian Al-Qur'an di Barat memang sangat menarik untuk dikaji karena bagaimanapun juga, peradaban mereka banyak dipengaruhi oleh peradaban Islam. Peradaban Islam yang begitu gemilang banyak juga terinspirasi oleh ayat-ayat Al-Qur'an. Sebelum Bagdad dihancurkan oleh tentara Hulagu Khan pada tahun 656 H/1258 M, dunia Islam penuh dengan kajian-kajian ilmiah yang menghasilkan beragam ilmu. Tetapi pada saat itu banyak karya-karya sarjana Muslim yang hilang, bahkan terbakar. Sejarah hanyalah tinggal namanya saja, namun spirit keilmuan tetap terus berkembang. Itulah sebabnya negara-negara Barat mulai tertarik mengkaji Islam melalui kitab suci al-Qur'an.

Apa yang penulis paparkan dalam tulisan ini masih bersifat umum dan hanya deskriptif, tentu banyak literatur yang membahas tentang topik-topik tertentu yang belum disebutkan atau dianalisis secara mendalam. Paling tidak bisa disimpulkan bahwa awal mula kesejarahan studi Al-Qur'an di Barat adalah lewat tradisi penerjemahan. Terjemahan Al-Qur'an sangat membantu seseorang untuk memahami isi kandungan Al-Qur'an meskipun tidak sepenuhnya. Abad ke-12 merupakan awal mula studi Al-Qur'an secara umum karena pada abad inilah penerjemahan Al-Qur'an mulai digalakkan dengan tokoh utamanya Robert of Ketton. Meskipun demikian hasil penerjemahan tersebut mulai diterbitkan pada abad ke 16, tepatnya tahun 1543. 
Harus diakui bahwa tidak semua kalangan orientalis yang mengkaji Islam (dalam hal ini al-Qur'an) memiliki niat jahat. Banyak juga hasil penelitian mereka yang bisa dijadikan pedoman dalam mengembangkan studi al-Qur'an. Kajian kritis yang dilakukan sarjanasarjana Barat menjadi tantangan tersendiri bagi sarjana-sarjana Muslim lainnya untuk berdiskusi dan berdialog. Tentu itu merupakan hal yang sangat bagus dalam pengembangan pemikiran yang kreatifinovatif. Tema-tema yang penulis paparkan dalam tulisan ini perlu dikembangkan lebih lanjut supaya data-data bisa dieksplorasi secara komprehensif dan sistematis. Sebenarnya apa yang dilakukan oleh sarjana-sarjana Barat sudah dilakukan oleh sarjana-sarjana Muslim sebelumnya dalam literatur Ulumul Qur'anatau sejarah al-Qur'an.

Sejak abad ke-12 sampai sekarang, kajian Al-Qur'an di dunia Barat masih menggema dengan berbagai macam metode dan pendekatan. Banyak karya-karya ilmiah lahir di dunia Barat dengan berbagai macam bentuk dan ragamnya. Sarjana-sarjana Muslim juga banyak mengambil ilmu dari kalangan orientalis yang memiliki kapasitas dalam kajian Al-Qur'an. Bahkan kumpulan artikel internasional dari berbagai pakar sudah dikumpulkan dalam bentuk eksiklopedi yang lengkap. Salah satunya adalah Encyclopaedia of the Qur'an yang editornya diketuai oleh Jane Dammen McAuliffe. Dia merupakan salah satu di antara sarjana Barat modern yang banyak mengkaji tentang Al-Qur'an sebagaimana sarjana-sarjana Barat sebelumnya atau yang semasa dengannya.

\section{DAFTAR PUSTAKA}

Abu Laylah, Muhammad M, The Qur'an and the Gospels: A Comparative Study, Kairo: Al-Falah Foundation for Translation, Publication \& Distribution, cet-III, 1426 H/2005 M.

Ahmad Zidan dan Dina Zidan, Translation of The Glorious Quran, Kuala Lumpur-Malaysia, A.S. Noordeen, cet-I, 1991 M. 
Alī, Abdullah Yūsuf, The Meaning of The Holy Qur'ān: Complete Translation with Selected Notes, Kuala Lumpur-Malaysia: Islamic Book Trust, cet-I, 1996.

Amal, Taufik Adnan, Rekonstruksi Sejarah al-Qur'an, Yogyakarta: Forum kajian Agama dan Budaya, cet-I, 2001.

Arif, Syamsuddin,Orientalis \& Diabolisme Pemikiran, Jakarta: Gema Insani Press, cet-I, 1429 H/2008 M.

Armas, Adnin, Metodologi Bibel dalam Studi Al-Quran: Kajian Kritis, Jakarta: Gema Insani Press, cet-III, 1428 H/2007 M.

Azami, M. M, Sejarah Teks Al-Qur'an dari Wahyu sampai Kompilasi: Kajian Perbandingan dengan Perjanjian Lama dan Perjanjian Baru,trj. Sohirin Solihin, dkk, Jakarta: Gema Insani Press, cet-III, $1429 \mathrm{H} / 2008 \mathrm{M}$.

Burton, John, The Collection of The Qur'an, Cambridge: Cambridge University Press, 1977.

Carter, Michael, "Foreign Vocabulary”, dalam Andrew Rippin (ed), The Blackwell Companion to The Qurān, USA: Blackwell Publishing, 2006. Daya,Burhanuddin,Pergumulan Timur Menyikapi Barat: Dasar-Dasar Oksidentalisme, Yogyakarta: Suka Press, cet-I, 2008.

Farīd, Malik Ghulām, The Holy Qur'an: English Translation \& Commentary, Pakistan: The Oriental and Religious Publishing Corporation Ltd, cet-I, 1969 M.

Hawting, G. R dan Abdul-Kader A Shareef, Approaches to the Qurān, Routledge: London and New York, cet-I, 1993.

Heiligmann, Manfred, Ada Apa dengan Alkitab?!: Kesalahan, Absurditas, Inkonsitensi dan Vulgaritas dalam Alkitab, Jakarta: Bina Communio, cet-I, 2011.

Husaini, Adian, Wajah Peradaban Barat: Dari Hegemoni Kristen ke Dominasi Sekular-Liberal,Jakarta: Gema Insani Press, cet-I, 1426 $\mathrm{H} / 2005 \mathrm{M}$. 
Ismail, Faisal, Paradigma Kebudayaan Islam: Studi Kritis dan Analisis Historis, Yogyakarta: SUKA Press, edisi revisi, cet-V, 2014.

Jeffery, Arthur, The Foreign Vocabulary of The Qur'ān, ed. Gerhard Bowering dan Jane Dammen McAuliffe Leiden-Boston: Brill, 2007. Julius, Wellhausen, The Religio-Political Faction in Early Islam, Amsterdam: North Holland Publisher, 1975.

Neuwirth, Angelika, Nicolai Sinai, dan Michael Marx (eds), The Quran in Context: Historical and Literary Investigations into the Qur'anic Milieu, Leiden-Boston: Brill, 2010.

Pickthall, Mohammed Marmaduke, The Meaning of the Glorious Koran: An Explonatory Translation, Delhi: World Islamic Publications, cet-III, $1981 \mathrm{M}$.

Puin, Gerd-R., "Observation on Early Qur'an Manuscripts in Șan’a”, dalam Stefan Wild (ed), The Qur'an As Text, Leiden: E.J. Brill, 1996

Rahman, Fazlur,Major Themes of the Qur'än,Minneapolis: Bibliotheca Islamica, 1989.

Rasyid, Daud "Pembaruan" Islam \& Orientalisme dalam Sorotan,Bandung: Syamil Publishing, cet-I, 2006.

Rippin, Andrew, Approches to the History of the Interpretation of the Qur'an, Oxford: Clarendon Press, 1988.

Saeed, Abdullah,The Qur'an: An Introduction, London and Yew York: Routledge, cet-I, 2008.

Said, Hasani Ahmad, Diskursus Munasabah Alquran dalam Tafsir AlMishbah, Jakarta: Amzah, cet-I, 2015.

Salim, Fahmi, Kritik Terhadap Studi Al-Quran Kaum Liberal,Jakarta: Perspektif, cet-I, 1431 H/2010 M.

Sirry, Mun'im, Polemik Kitab Suci: Tafsir Reformis Atas Kritik Al-Qur'an terhadap Agama Lain, trj. R. Cecep Lukman Yasin, Jakarta: PT Gramedia Pustaka Utama, 2013. 
Weil, Gustav, The Bible, The Koran, and The Talmud, London: Longman,Brown, Green, Longmans, 1846.

Wild, Stefan,"We Have Sent Down to Thee the Book with the Truth: Spatial and Temporal Implications of the Quranic Concept of Nuzūl, Tanzīl, and Inzāl", dalam Stefan Wild, ed. The Quran As Text, Leiden- New York - Koln: E.J. Brill, 1996.

Zammit, Martin R. A Comparative Lexical Study of Qur'anic Arabic, Leiden-Boston: Brill, 2002. 